\title{
Differences in follicular aromatase activity between Meishan and Large-White hybrid gilts
}

\author{
M. G. Hunter, C. Biggs, A. R. Pickard and L. S. Faillace \\ Department of Physiology and Environmental Science, Faculty of Agricultural and Food Sciences, \\ University of Nottingham, Sutton Bonington Campus, LE12 5RD, UK
}

\begin{abstract}
Two experiments were carried out in which follicular aromatase activity was compared between Meishan and Large-White hybrid gilts. In Expt 1, preovulatory follicles $(n=10$ largest per animal) were recovered from Meishan and Large-White hybrid gilts ( $n=5$ per breed) on the day before predicted onset of behavioural oestrus, and the granulosa cells and theca tissue incubated to determine aromatase activity. Follicles recovered from Meishan pigs were smaller $(P<0.01)$ and contained fewer granulosa cells $(P<0.05)$, but follicular oestradiol content of the breeds was similar $(P>0.1)$. Aromatase activity was higher in the theca tissue $(P<0.05)$ and tended to be higher in the granulosa cells recovered from Meishan follicles $(P=0.065)$. In Expt 2 , granulosa cell aromatase activity was investigated during the early follicular phase (estimated day 16 of cycle) in Meishan and Large-White hybrid gilts ( $n=6$ and 5 , respectively). The number of follicles $\geq 1 \mathrm{~mm}$ diameter recovered per animal was 171 for both breeds $(P>0.1)$, whereas the number of follicles $\geq 2 \mathrm{~mm}$ diameter was 65 and $101 \quad(P<0.05)$ from Meishan and Large-White hybrid gilts, respectively. The mean diameter of all follicles recovered was smaller in the Meishan gilts $(P<0.001)$. Overall, neither the number of granulosa cells per follicle, as indicated by DNA estimation, nor the oestradiol content differed between the breeds at this time $(P>0.1)$. Mean aromatase activity was assessed in granulosa cells recovered from alternate follicles $\geq 3 \mathrm{~mm}$ diameter and was higher in the Meishan gilts when expressed per $\mu \mathrm{g}$ DNA $(P \leq 0.025)$. As follicle diameter increased, the difference in aromatase activity between the breeds became more pronounced $(P<0.05)$. These results indicate that Meishan follicles have higher aromatase activity in the granulosa and theca cells during both the early and late follicular phase, compared with Large-White hybrid follicles. Whether this has a role in ensuring the prolificacy of the Meishan pig requires further investigation.
\end{abstract}

\section{Introduction}

The Chinese Meishan pig is extremely prolific when compared with European breeds (Bazar et al., 1988a, b; Haley and Lee, 1990), and can produce up to $30-40 \%$ more live piglets per litter. Although the precise physiological basis for the enhanced prolificacy is unknown, it has been reported to result from increased prenatal survival for a given ovulation rate (Wilmut et al., 1992). Thus, the Meishan pig gains its advantage from enhanced embryonic survival, and this is evident even when ovulation rate is comparatively low (Bazer ef al., 1988b). Variation in the rate of development of preimplantation embryos within a litter, resulting from a heterogeneous preovulatory follicle population, has been suggested to be a likely cause of the high embryonic loss in European breeds of pig (Anderson, 1978; Pope et al., 1990). Bazer et al. (1988b) reported an increased uniformity of blastocyst development in the prolific Meishan pigs and, furthermore, studies by Terqui et al. (1992) have demonstrated that the high embryo survival

Received 2 August 1993. is due to 'faster' embryonic development, which may be a consequence of improved oocyte maturation.

Results from a previous investigation of follicular characteristics in Meishan and Large-White hybrid gilts (Biggs et al, 1993) found no difference between the breeds in the heterogeneity of follicles recovered during the preovulatory period. However, it was established that preovulatory follicles of Meishan pigs, despite being smaller than those of Large-White hybrid pigs, contain the same total amount of oestradiol. The oestradiol concentration in the follicular fluid is therefore increased in Meishan follicles (Biggs et al., 1993). These results suggest that a population of Meishan follicles may be at a more advanced stage of maturity than a comparable population of follicles from Large-White hybrid pigs, a characteristic that may be related to the increased prolificacy in these animals.

The aetiology of the enhanced oestradiol concentration in the Meishan follicular fluid could be due to an increased number of granulosa cells, earlier activation of aromatase activity, increased aromatase activity per cell or increased androgen substrate availability. The aim of the current studies therefore was to investigate these possibilities using follicles Downloaded from Bioscientifica.com at 04/26/2023 01:40:51AM 
recovered during the early and late follicular phase from both Meishan and Large-White hybrid gilts.

\section{Materials and Methods}

\section{Animals}

Experiment 1. Five prepubertal Meishan and five prepubertal Large-White hybrid [Landrace $\times$ (Landrace $\times$ Large White)] gilts were penned according to breed. Vasectomized boars of the appropriate breed were introduced daily to stimulate the onset of puberty and to allow an accurate detection of the onset of oestrus. Once they had exhibited at least two regular oestrous cycles, five gilts of each breed were killed and the ovaries removed the day before predicted oestrus (day 20 for a 21-day cycle, when the follicles are highly oestrogenic; Biggs et al., 1993). The average duration of the cycle and the time of the last oestrus were used to decide the date on which the animals were killed.

Experiment 2. Six prepubertal Meishan and five prepubertal Large-White hybrid gilts were penned and their time of oestrus detected as described above. Gilts were killed and ovaries recovered on predicted day 16 (i.e. during the follicular recruitment period; Hunter et al., 1993) of the sixth or seventh oestrous cycle.

\section{Collection and treatment of follicular tissue}

Experiment 1. The methods for handling and dissection of the ten largest follicles, the collection of follicular fluid and the harvesting of granulosa cells were as reported by Foxcroft $e t$ al. (1987), Grant et al. (1989) and Hunter et al. (1989). In addition, granulosa cell counts from individual follicles were obtained using a haemocytometer, and the isolated thecal tissue from each follicle was weighed and minced.

Incubations for aromatase activity were performed by the methods of Foxcroft et al. (1987) on the granulosa cell suspensions. Before the experiment, the aromatase assay had been validated using tissue recovered from naturally cyclic Meishan and Large-White hybrid animals. The timecourse of oestradiol production was found to follow the same pattern in both breeds, and an incubation of $2 \mathrm{~h}$ was selected as this fell within the time of linear production of oestradiol in both breeds (Biggs, 1993). Duplicate $100 \mu$ laliquots of the granulosa cell suspension $\left(4 \times 10^{5}\right.$ cells per tube) were incubated, both in the presence (100 $\mathrm{ng} \mathrm{ml}^{-1}$ ) and absence of testosterone, in a total volume of $1 \mathrm{ml}$ basal medium Eagles (BME: Flow Laboratories, Irvine) containing 0.1\% BSA (Fraction V, Sigma Chemical $\mathrm{Co}$, Poole). The aromatase activity of the thecal tissue was estimated by a method based on that of Tsang et al. (1979) and validated by Biggs (1993) using duplicate weighed aliquots of the minced thecal tissue incubated in $1 \mathrm{ml}$ of BME-BSA. Again, a comparison between breeds showed a similar pattern of oestradiol production.

Cell suspensions or tissue minces were incubated at $37^{\circ} \mathrm{C}$ in a shaking water bath and the incubations terminated after $2 \mathrm{~h}$ by transferring the tubes to a freezer at $-20^{\circ} \mathrm{C}$ for subsequent oestradiol determination by radioimmunoassay; the theca incubations were also assayed for testosterone. The theca cell aromatase activity was expressed as the amount of oestradiol released during $2 \mathrm{~h}$ per follicle and also per mg of tissue. The granulosa cell aromatase activity was calculated by subtracting the oestradiol production from cells without substrate from the oestradiol production from cells with added testosterone, and expressed as either oestradiol production during $2 \mathrm{~h}$ per follicle or per $4 \times 10^{5}$ cells. The amount of oestradiol in follicular fluid was expressed in $\mathrm{ng} \mathrm{ml}^{-1}$ of follicular fluid, and also as the total content of oestradiol per follicle. The testosterone in the thecal incubates was expressed per mg of tissue and per follicle.

Experiment 2. All follicles $\geq 1 \mathrm{~mm}$ diameter were dissected and counted. All follicles $\geq 3 \mathrm{~mm}$ were ranked on the basis of their diameter; fluid was aspirated; and granulosa cells were recovered from alternate follicles (Grant et al., 1989) and resuspended in $0.6 \mathrm{ml}$ BME-BSA. Duplicate aliquots of $100 \mu \mathrm{l}$ of the final cell suspension were incubated alone or in the presence of $100 \mathrm{ng}$ testosterone $\mathrm{ml}^{-1}$. Aromatase activity per follicle was calculated as described above. A further $100 \mu \mathrm{l}$ aliquot of the cell suspension was used for determination of DNA content according to the method of Labarca and Paigen (1980). The range of the standard curve was 1.25-20 $\mu \mathrm{g}$ DNA and interassay and intra-assay coefficients of variation were $8.3 \%$ and $10.5 \%$, respectively.

\section{Hormone radioimmunoassays}

Concentrations of oestradiol in the follicular fluid and incubation media were determined by direct radioimmunoassay as described by Grant et al. (1989). The limit of sensitivity was 4.I pg per tube and the interassay and intra-assay coefficients of variation were 15.3 and $8.6 \%$, respectively. Similarly, testosterone concentrations in theca incubations were measured as described by Grant et al. (1989). The interassay and intra-assay coefficients of variation were 10.7 and $7.2 \%$, respectively, and the limit of sensitivity of the assay was $12.0 \mathrm{pg}$ per tube.

\section{Statistical analysis}

The data were analysed by analysis of variance (GENSTAT statistical package (Genstat 5 Committee, 1989)), using breed as treatment and the individual animals as a block structure. The total degrees of freedom was equal to the number of animals, and the pooled variance was used to calculate the standard error of the difference (SED). In Expt 1, as all follicles were presumed to be preovulatory, the total amount of follicular oestradiol was used as a covariate for the analysis of the aromatase incubations. In Expt 2, follicular DNA content was analysed by multiple regression analysis using a model that included animal, breed, follicle diameter and the interaction of breed with follicle diameter. Follicular fluid oestradiol and aromatase activity per follicle were analysed by multiple regression analyses using models that included animal, breed, an indicator of follicle maturity (either follicle diameter or follicular DNA content) and the interaction of breed with the particular measure of follicle maturity. The effects of breed and its interactions in these regression models were tested for significance using the mean square for the effect of animal Downloaded from Bioscientifica.com at 04/26/2023 01:40:51AM 


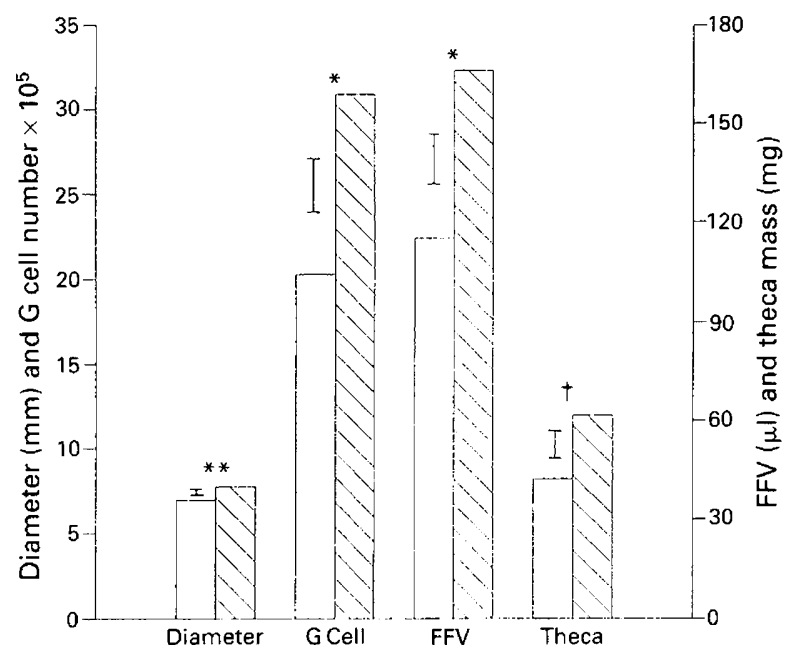

Fig. 1. Means and SED of follicular diameter, granulosa cell number $(\mathrm{G}$ cell), follicular fluid volume (FFV) and theca mass (Theca) of the ten

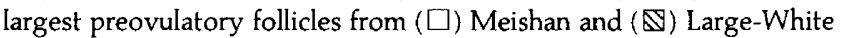
hybrid gilts ( $n=5$ per breed) recovered on day 20 of the oestrous cycle (Expt 1). ${ }^{*} P<0.05 ;{ }^{* *} P<0.01 ;{ }^{\dagger} P=0.06$.

(rather than the error mean square) as the denominator in the variance ratio. In both experiments, since there was much variation both within and between animals, significance levels of $P<0.1$ were considered to indicate a trend, and levels of $P \leq 0.05$ were considered to be significant.

\section{Results}

\section{Follicle numbers and size}

Experiment 1. Numbers of corpora lutea from the previous cycle did not differ between the breeds ( 14.7 versus 14.2 for Meishan and Large-White hybrid pigs, respectively; $\operatorname{SED}=2.8$; $P>0.1)$. Follicles from Meishan pigs were smaller $(P<0.01)$ and contained less follicular fluid $(P<0.05)$ (Fig. 1 ). The number of granulosa cells was also lower in the Meishan follicles $(P<0.05)$ and there was a tendency for the theca tissue to weigh less in Meishan than in Large-White hybrid gilts $(P=0.06)$ (Fig. 1).

Experiment 2. Numbers of corpora lutea from the previous cycle did not differ between the breeds ( 16.8 versus 15.5 for Meishan and Large-White hybrid pigs, respectively; SED $=2.1$; $P>0.1$ ). The mean total number of antral follicles $\geq 1 \mathrm{~mm}$ diameter per animal was similar between the two breeds (171 for both Meishan and Large-White hybrid gilts, respectively; $\mathrm{SED}=35.2 ; P>0.1$ ), but there were more follicles $\geq 2 \mathrm{~mm}$ in the Large-White hybrid gilts (101.6 versus 65.0 ; $\mathrm{SED}=14.3$; $P<0.05$ ). The overall mean diameter of follicles $\geq 1 \mathrm{~mm}$ was smaller in Meishan gilts than in Large-White hybrid gilts ( $2.23 \mathrm{~mm}$ versus $2.65 \mathrm{~mm}$; SED $=0.06 ; P<0.001$ ). When all the follicles $\geq 1 \mathrm{~mm}$ diameter were divided into discrete size classes (Fig. 2), Large-White gilts had more follicles in every size class except those $<2 \mathrm{~mm}$ than did Meishan gilts. This difference was significant in the $\geq 4-<5$ class $(P<0.05)$, and

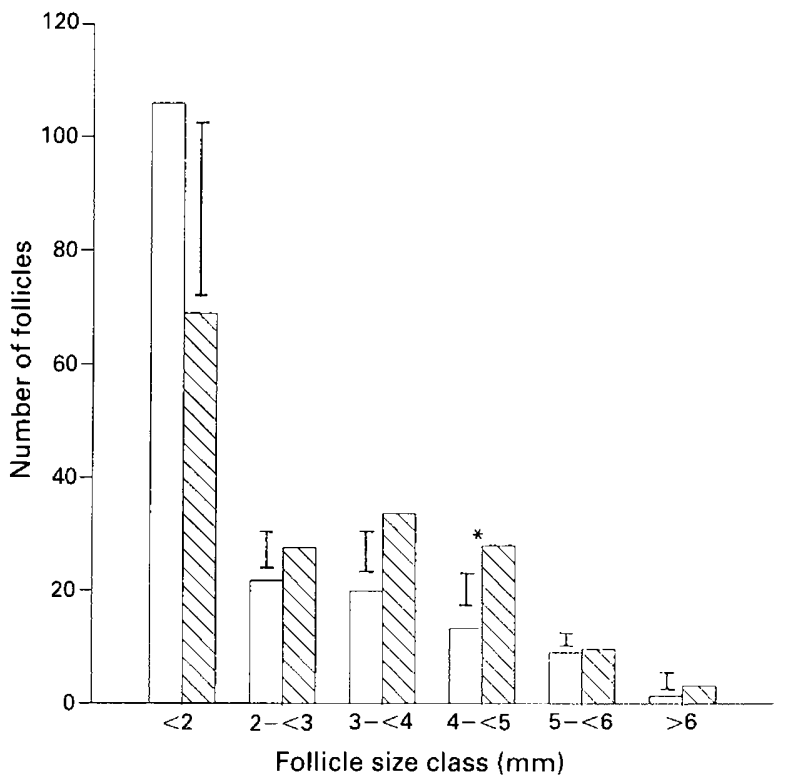

Fig. 2. Means and SED of numbers of follicles recovered on day 16 of the oestrous cycle in each of six follicle size classes as determined by follicular diameter from $(\square)$ Meishan ( $n=6,1024$ total follicles) and (\$) Large-White hybrid ( $n=5,854$ total follicles) gilts (Expt 2). $* P<0.05$.

tended to be different in the $\geq 3-<4 \mathrm{~mm}$ class $(P=0.07)$. Follicular fluid volume of follicles $\geq 3 \mathrm{~mm}$ was not different between the breeds $(17.0 \mu \mathrm{l}$ for Meishan and $18.6 \mu \mathrm{l}$ for Large-White hybrid gilts; SED $=5.6 ; P>0.1$ ). The number of granulosa cells per follicle was variable but did not differ significantly according to breed $(P=0.11)$, as indicated by the DNA content of granulosa cells harvested from each follicle (9.4 $\mu \mathrm{g}$ for Meishan and $18.3 \mu \mathrm{g}$ for Large-White hybrid gilts; SED $=5.0)$. DNA content increased $(P<0.05)$ with increasing follicular diameter in both breeds.

\section{Oestradiol content of follicular fluid}

Experiment 1. The amount of oestradiol in follicular fluid was not significantly different between the breeds whether expressed on a per follicle basis $(67$ and $72 \mathrm{ng}$ for Meishan and Large-White hybrid pigs, respectively; $\mathrm{SED}=23.5 ; P>0.1$ ) or as a concentration in the follicular fluid $\left(582\right.$ and $414 \mathrm{ng} \mathrm{ml}^{-1}$ for Meishan and Large-White hybrid pigs, respectively; SED $=105$; $P>0.1)$.

Experiment 2. The oestradiol content of the follicular fluid from follicles $\geq 3 \mathrm{~mm}$ did not differ according to breed whether expressed on a per follicle basis $(0.72$ and $1.08 \mathrm{ng}$ for Meishan ( $n=260$ follicles) and Large-White hybrid $(n=371$ follicles) gilts, respectively; $\mathrm{SED}=1.35 ; P>0.1$ ) or as a concentration in the follicular fluid $\left(29.2\right.$ and $26.4 \mathrm{ng} \mathrm{ml} \mathrm{m}^{-1}$ for Meishan and Large-White hybrid gilts, respectively, SED $=26.4$; $P>0.1$ ). Overall, oestradiol content significantly increased with increasing follicle maturity whether indicated by follicle diameter $(P<0.001$, when expressed per follicle; $P<0.005$, and when expressed as $\mathrm{ng} \mathrm{ml}^{-1}$ follicular fluid) or granulosa cell 


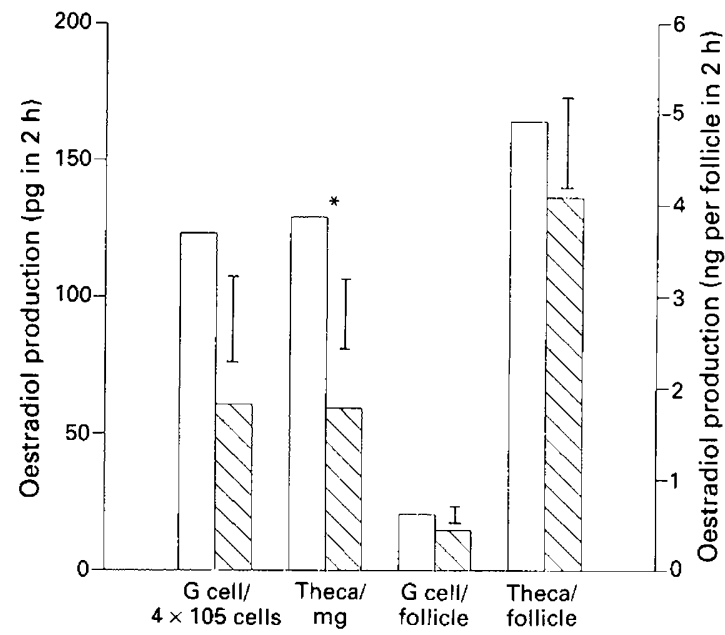

Fig. 3. Means and SED of oestradiol production as a measure of aromatase activity, from granulosa cells and thecal tissue of the ten largest preovulatory follicles recovered on day 20 of the oestrous cycle from ( $\square$ ) Meishan and ( $\$$ ) Large-White hybrid gilts ( $n=5$ per breed) expressed for granulosa cells per $4 \times 10^{5}$ cells ( $\mathrm{G} \mathrm{Cell} / 4 \times 10^{5}$ cells: pg in $2 \mathrm{~h}$ ) and per follicle ( $\mathrm{G}$ cell/follicle: ng per follicle in $2 \mathrm{~h}$ ), and for theca per mg mass (Theca/mg: pg in $2 \mathrm{~h}$ ) and per follicle (Theca/follicle: ng per follicle in $2 \mathrm{~h}$ ) (Expt 1). ${ }^{*} P<0.05$.

DNA content $(P<0.02$, when expressed per follicle or ng $\mathrm{ml}^{-1}$ follicular fluid).

\section{Aromatase activity}

Experiment 1. Oestradiol production by the granulosa cells is shown in Fig. 3, and is expressed as per number of cells and per follicle. Although the amount of oestradiol secreted tended to be higher in Meishan gilts when expressed per cell $(P=0.067)$, there was no difference between the breeds when expressed per follicle $(P>0.1)$. However, aromatase activity in the theca tissue was significantly higher in the Meishan gilts when expressed per $\mathrm{mg}$ of tissue $(P<0.05)$, although there was no significant difference when expressed on a per follicle basis (P> 0.1; Fig. 3).

The amount of testosterone secreted into the medium during the $2 \mathrm{~h}$ incubation did not differ between the breeds $(P>0.1)$ whether expressed per $\mathrm{mg}$ of theca tissue $(0.12$ and $0.06 \mathrm{ng}$ $\mathrm{mg}^{-1}$ for Meishan and Large-White hybrid gilts, respectively; SED $=0.03$ ) or per follicle (5.2 and 4.1 ng per follicle, SED $=2.1$ ).

Experiment 2. Aromatase activity was higher in granulosa cells of follicles from Meishan ( $n=6$ animals, 127 total follicles) than from Large-White hybrid ( $n=5$ animals, 196 total follicles) gilts when expressed either as oestradiol produced per follicle $(P=0.059)$ or per $\mu$ g DNA $(P<0.025$; Fig. 4). Furthermore, aromatase activity per follicle increased with increasing follicular diameter overall $(P<0.001)$, but, more importantly, a significant follicle diameter by breed interaction $(P<0.05)$ indicated that as follicle diameter increased the difference in aromatase activity between the breeds became more pronounced (Fig. 5).

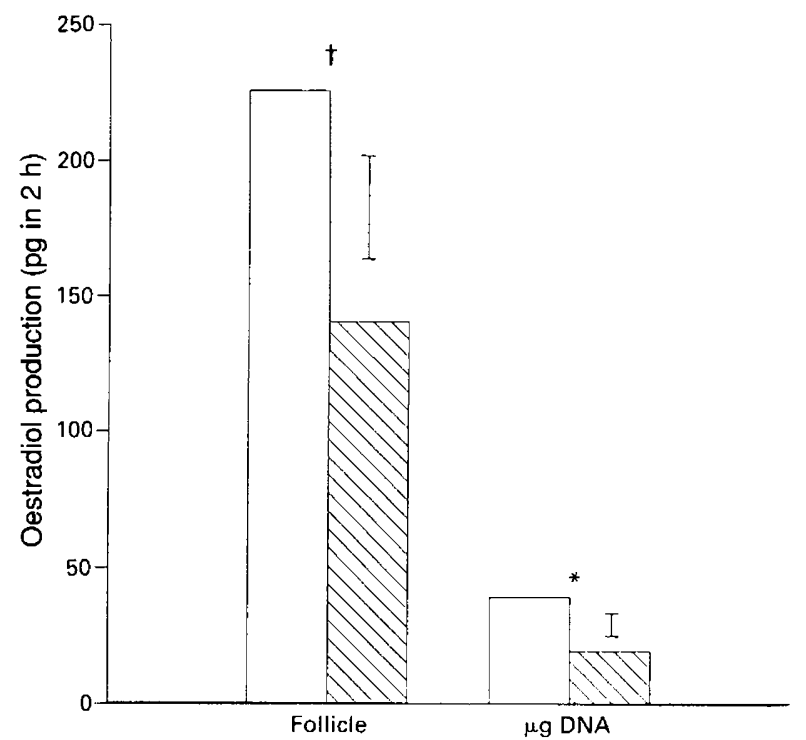

Fig. 4. Means and SED of oestradiol production, as a measure of aromatase activity in granulosa cells from alternate follicles recovered on day 16 of the oestrous cycle having a diameter of $\geq 3 \mathrm{~mm}$ from ( $\square$ ) Meishan ( $n=6,127$ total follicles) and ( $\$$ ) Large-White hybrid gilts ( $n=5,196$ total follicles). Aromatase activity was measured by granulosa cell oestradiol production and is expressed on a per follicle and a per $\mu \mathrm{g}$ of DNA basis (Expt 2). ${ }^{*} P<0.05 ;{ }^{\dagger} P<0.059$.

\section{Discussion}

These experiments confirm and extend previous observations on the preovulatory follicular population in Meishan pigs (Biggs et al., 1993) and show that the mean diameter of the follicle population with diameter $\geq 1 \mathrm{~mm}$ present during the early follicular phase is smaller in Meishan than in Large-White hybrid gilts. Although a similar number of follicles $\geq 1 \mathrm{~mm}$ diameter was recovered for each breed in Expt 2, more of these follicles were $\geq 2 \mathrm{~mm}$ in diameter in Large-White hybrid than in Meishan gilts. This finding shows that the overall number of follicles in the proliferating pool (i.e. $\geq 1 \mathrm{~mm}$ ) was not different between the breeds and is consistent with earlier findings that ovulation rate does not differ between breeds in gilts of similar reproductive age to those used in the present study (Hunter et al., 1993).

The overall mean concentration of oestradiol in the follicular fluid was not significantly different between the breeds in either of the experiments reported here, which initially may appear to contradict earlier findings of a higher follicular fluid oestradiol concentration in Meishan gilts (Biggs et al., 1993) during the preovulatory period. However, the mean concentration was numerically higher in preovulatory Meishan follicles (Expt 1) and although this difference was not significant, it is consistent with earlier findings using larger numbers of animals. Since follicles were recovered during the early follicular phase in Expt 2 , oestradiol concentrations were much lower overall and extremely variable, but not different between the breeds. At this stage, however, the pool of follicles would have contained both growing and regressing follicles with very low oestrogenic activity. In contrast, the ten largest preovulatory follicles investigated in Expt 1 were at peak oestrogenic activity and Downloaded from Bioscientifica.com at 04/26/2023 01:40:51AM 


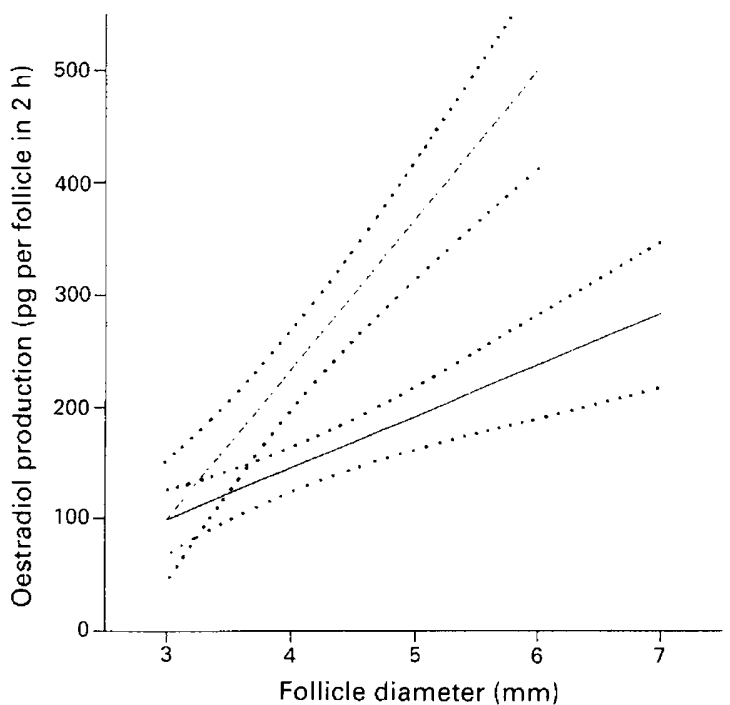

Fig. 5. Regression lines and $95 \%$ confidence intervals for the influence of follicular diameter on granulosa cell oestradiol production as a measure of aromatase activity for Meishan gilts (broken line, $n=6$, 127 total follicles) and Large-White hybrid gilts (solid line, $n=5,196$ total follicles) follicles recovered on day 16 of oestrous cycle. Aromatase activity was measured by granulosa cell oestradiol production and is expressed on a per follicle basis (Expt 2). $P<0.001$, overall relationship between diameter and aromatase activity; $P<0.05$, diameter by breed interaction.

therefore had very high follicular fluid oestradiol concentrations. If there are breed differences in the follicular fluid oestradiol content of growing follicles during the early part of the follicular phase, they may therefore have been masked in Expt 2 by the investigation of a larger follicular population.

The number of granulosa cells was lower in preovulatory Meishan follicles, which is consistent with their smaller size. A previous study by Biggs et al. (1993) did not detect any differences in granulosa DNA content between the breeds at a similar stage of follicle development, but in that study all preovulatory follicles were investigated, whereas in the present study only the ten largest follicles per animal were studied. Earlier in the follicular phase (Expt 2), the number of granulosa cells (as indicated by DNA content) did not differ between the breeds, regardless of follicle size; however, few follicles in this experiment were of a comparable size to the preovulatory follicles of Expt 1. In addition, as mentioned previously, the populations of follicles examined in Expt 2 were much more heterogeneous in terms of their physiological status than were those of Expt 1 ; thus, it is perhaps not surprising that significant differences in DNA content were not detected in these follicles on day 16. This hypothesis is supported by findings that the number of granulosa cells is extremely variable, even among follicles of similar size (Foxcroft and Hunter, 1985).

Mean aromatase activity tended to be higher in granulosa cells from Meishan follicles when expressed on a per cell basis in Expt 1, and on a per follicle basis in Expt 2. This difference was significant in Expt 2 when expressed per $\mu \mathrm{g}$ DNA. This means that in spite of their smaller size, the follicles of Meishan pigs were at least as active oestrogenically as those of Large-
White hybrid pigs, if not more so. Aromatase activity in the theca tissue (Expt 1) was also significantly higher in the Meishan follicles when expressed on a basis of mass. Pig follicles are unusual compared with those of other species such as sheep and cows, in that the theca tissue also possesses aromatase activity and thus is capable of independent oestradiol production (Evans et al., 1981; Tonetta et al., 1988). It has even been suggested that the theca contributes at least as much as the granulosa to the circulating oestradiol concentration (Evans et al., 1981). Secretion of testosterone by the theca tissue during incubation does not differ between the breeds. However, it is difficult to draw firm conclusions from these results regarding overall testosterone synthesis, as more androgen was converted to oestradiol in the theca tissue from Meishan follicles. The use of a specific aromatase inhibitor would enable the measurement of total androgen production and this area needs further evaluation, particularly since Grant et al. (1989) concluded that the availability of the androgen substrate was critical for maintaining follicular oestradiol synthesis.

The mechanism by which the Meishan gilt gains the increased follicular aromatase activity is uncertain at present. Erickson and Hsueh (1978) established FSH as the principal gonadotrophic stimulant of granulosa cell aromatase activity. Studies in prolific sheep have implicated increased follicular sensitivity to $\mathrm{FSH}$ as a determinant of the increased ovulation rate (Bindon and Piper, 1986). Thus, although the peripheral concentration of FSH is similar between breeds, more follicles will ovulate in response to the preovulatory $\mathrm{LH}$ surge in prolific breeds of sheep. Circulating FSH concentrations have been shown to be similar between Meishan and Large-White hybrid gilts with the same ovulation rate during the periovulatory period (Hunter et al., 1993). However, the status of the plasma FSH concentrations in older, highly ovulating Meishan sows or during the early follicular phase in younger Meishan sows or gilts is unknown. It is possible that increased sensitivity to FSH in the Meishan follicles, or increased FSH receptor content results in the higher aromatase activity reported in this study and this may have consequences for the later development of the oocyte and embryo. However, it should be noted that FSH receptors are present only on granulosa cells, and so would not play a role in controlling thecal aromatase activity (Foxcroft and Hunter, 1985).

A consistent feature that has been noted in this and other studies of prolific Meishan pigs is the smaller diameter of their preovulatory follicles (Biggs et al., 1993), a characteristic that has also been reported for prolific breeds of sheep (Driancourt et al., 1985; McNatty et al., 1985; Driancourt et al., 1991). In accordance with the smaller follicle diameters noted in Meishan pigs and in prolific sheep breeds is the finding that the preovulatory follicles of these prolific breeds contain fewer granulosa cells. Notwithstanding, peak granulosa cell aromatase activity has been shown to be achieved in relatively small follicles $(3-4.5 \mathrm{~mm})$ from prolific Booroola $\times$ Merino ewes compared with that measured in follicles from non-prolific lines of the crossbreed ( $\geq 5 \mathrm{~mm}$; McNatty et al., 1986). The similarities between the characteristics observed in prolific pigs and sheep raises the possibility that the same mechanisms may be used in both species to increase fecundity. However, comparisons with prolific breeds of sheep must be viewed with caution as sheep appear to achieve their prolificacy by an Downloaded from Bioscientifica.com at 04/26/2023 01:40:51AM 
increased ovulation rate, whereas Meishan pigs appear to achieve their prolificacy by increased embryo survival and also a high ovulation rate in some circumstances. Nevertheless, these comparisons are valid, since it is possible that the underlying mechanism of enhanced prolificacy in both species may involve more follicles being able to respond effectively and more synchronously to the LH surge.

The oestrogenic nature of the Meishan follicles may play a role in the prolificacy of this breed since these follicles are likely to be able to respond to the LH surge and luteinize effectively as well as produce viable ova (Hunter and Weisak, 1990). Indeed, it has been shown that a higher percentage of oocytes have matured to the metaphase II stage within the $8 \mathrm{~h}$ period prior to the predicted time of ovulation in Meishan than in Large-White hybrid gilts, suggesting enhanced maturation and thus quality of Meishan oocytes (Faillace et al., 1992). Meishan follicles, although smaller in size, may therefore have an intrafollicular environment that is at a more advanced stage of maturation in terms of the oestrogenic environment and presumably other regulatory factors.

In conclusion, these studies have confirmed that preovulatory follicles in Meishan gilts have a smaller diameter than do those of Large-White hybrids, and have extended this observation to the early follicular phase. Granulosa cell aromatase activity was higher in Meishan follicles recovered during the early follicular phase and showed a similar trend in preovulatory follicles. Theca tissue from preovulatory Meishan follicles also had higher aromatase activity than did tissue from Large-White hybrid gilts. It is suggested that this may be a component of the prolificacy of Meishan pigs.

The authors acknowledge the AFRC for financial support: C. Biggs was in receipt of a MAFF postgraduate scholarship. They thank C. Bowskill, L. Faillace and members of the Joint Animal Breeding Unit for technical assistance and H. M. Picton for assistance with the manuscript. The British Meishan Consortium is acknowledged for supply of animals.

\section{References}

Anderson LL (1978) Growth, protein content and distribution of early pig embryos Anatomical Record 190 143-155

Bazer FW, Thatcher WW, Martinat-Botte F and Terqui M (1988a) Sexual maturation and morphological development of the reproductive tract in Large White and prolific Chinese Meishan pigs Journal of Reproduction and Fertility $83723-728$

Bazer FW, Thatcher WW, Martinat-Botte F and Terqui M (1988b) Conceptus development in Large White and prolific Chinese Meishan pigs Journal of Reproduction and Fertility 84 37-42

Biggs C (1993) Endocrine and Ovarian Function in Meishan Pigs. PhD Thesis, University of Nottingham

Biggs C, Tilton JE, Craigon J, Foxcroft GR, Ashworth CJ and Hunter MG (1993) Comparison of follicular heterogeneity and ovarian characteristics in Meishan and Large-White hybrid pigs Journal of Reproduction and Fertility 97 263-269

Bindon BM and Piper LR (1986) The reproductive biology of prolific sheep breeds Oxford Reviews of Reproductive Biology 8 414-445

Driancourt MA, Cahill LP and Bindon BM (1985) Ovarian follicular populations and preovulatory enlargement in Booroola and control Merino ewes Journal of Reproduction and Fertility 73 93-107
Driancourt MA, Fry RC, Campbell BK and McNeilly AS (1991) Granulosa cell content and production of steroids, inhibin and follicular peptides by large follicles from a range of prolific and non-prolific sheep breeds journal of Reproduction and Fertility Supplement 43 230-231

Erickson GF and Hsueh AJW (1978) Stimulation of aromatase activity by follicle stimulating hormone in rat granulosa cells in vivo and in vitro Endocrinology 102 1275-1281

Evans G, Dobias M, King GJ and Armstrong DT (1981) Estrogen, androgen and progesterone biosynthesis by theca and granulosa of preovulatory follicles in the pig Biology of Reproduction 69 677-683

Faillace LS, Biggs C, Craigon J and Hunter MG (1992) Preovulatory ovarian processes in Meishan and Large White gilts Journal of Reproduction and Fertility Abstract Series 1025

Foxcroft GR and Hunter MG (1985) Basic physiology of follicular maturation in the pig Journal of Reproduction and Fertility Supplement 33 I-19

Foxcroft GR, Shaw HJ, Hunter MG, Booth PJ and Lancaster RT (1987) Relationships between luteinizing hormone, follicle stimulating hormone and prolac tin secretion and ovarian follicular development in the weaned sow Biology of Reproduction 36 175-191

Genstat 5 Committee (1989) Genstat 5 Reference Manual. Clarendon Press, Oxford

Grant SA, Hunter MG and Foxcroft GR (1989) Morphological and biochemical characteristics during ovarian follicular development in the pig Journal of Reproduction and Fertility 86 171-183

Haley CS and Lee GS (1990) Genetic components of litter size in Meishan and Large White pigs and their crosses Proceedings of the 4th World Congress of Genetics Applied to Livestock Production (Edinburgh) XV 458-461

Hunter MG and Wiesak (1990) Evidence for and implications of follicular heterogeneity in pigs Journal of Reproduction and Fertility Supplement $\mathbf{4 0}$ 163-171

Hunter MG, Grant SA and Foxcroft GR (1989) Histological evidence for heterogeneity in the development of preovulatory pig follicles Journal of Reproduction and Fertility 86 165-170

Hunter MG, Biggs C, Foxcroft GR, McNeilly AS and Tilton JE (1993) Comparisons of endocrinology and behavioural events during the periovulatory period in Meishan and Large-White hybrid gilts Joumal of Reproduction and Fertility 97 475-480

Labarca C and Paigen K (1980) A simple, rapid and sensitive DNA assay procedure Analytical Biochemistry 102 344-352

McNatty KP, Henderson KM, Lun S, Heath DA, Ball K, Hudson NL, Fennin J, Gibb M, Kieboom LE and Smith P (1985) Ovarian activity in Booroola $\times$ Romney ewes which have a major gene influencing their ovulation rate Journal of Reproduction and Fertility 77 193-205

McNatty KP, Lun S, Heath DA, Ball K, Smith P, Hudson N, McDiarmid J, Gibb M and Henderson KM (1986) Differences in ovarian activity between Booroola $\times$ Merino ewes which were homozygous, heterozygous and non carriers of a gene influencing their ovulation rate Journal of Reproduction and Fertility 77 193-205

Pope WF, Xie S, Broermann DM and Nephew KP (1990) Causes and consequences of early embryonic diversity in pigs Journal of Reproduction and Fertility Supplement 40 251-260

Terqui M, Bazer FW and Martinat-Botte F (1992) Mechanisms of high embryo survival in Meishan gilts. Proceedings of the International Symposium on Chinese Pig Breeds (Harbin) pp 52-59 Ed. C. Runsheng. Northeast Forestry University Press, Harbin

Tonetta SA, Devinna RS and DiZerega GS (1988) Effects of follicle regulatory protein on thecal aromatase and 3ß-hydroxysteroid dehydrogenase activity in medium and large sized pig follicles Joural of Reproduction and Fertility $\mathbf{8 2}$ 163-171

Tsang BK, Leung PCK and Armstrong DT (1979) Inhibition by estradiol-17 $\beta$ of porcine thecal androgen production in vitro Molecular and Cellular Endocrinology 14 131-140

Wilmut I, Ritchie WA, Haley CS, Ashworth CJ and Aitken RP (1992) A comparison of rate and uniformity of embryo development in Meishan and Large White pigs joumal of Reproduction and Fertility 95 45-56 